UDC $\quad 621.774 .21 .06: 621.313 .3: 621.3 .016$

論文

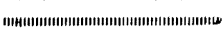

\title{
スパイラル造管機の主駆動電動機の負荷解析について*
}

\author{
津山豊 雄**
}

\section{Load Analysis of Main Driving Motor of Spiral Pipe Mill}

Toyowo Tsuyama

\section{Synopsis :}

The process of spiral pipe mill consists of preparation, forming and welding. In this study, resistance forces in each working process are calculated theoretically, and the load, which is required to carry strip and pipe, is also taken into consideration. The total load is compared with the indicated load on main driving motor of spiral pipe mill, and both values are shown to agree well each other. Dynamical behavior in each working process in the spiral pipe forming is also analyzed.

\section{1. 緒言}

スパイラル造管機の作業は前処理，成形および溶接か ら成り立つている.

本報告は造管における各工程の力の挙動を理論的に解 析し，その総合負荷を算出し，これと指示計の負荷とを 比較した.

\section{2.スパイラル鋼管の成形に関する 幾何学的関係}

スパイラル 鋼管の 成形には一定の 幾何学的関係があ り，これはスパイラル鋼管製造者が成形ならびに生産量 を検討する際に用いる基本法則である。

Fig. 1 に幾何学的関係図を示している.

ここで,

$B \quad$ : サイドトリーミング後のストリップの幅

$\begin{array}{rlr}S & =\text { ストリップの厚さ } & (\mathrm{mm}) \\ D & =\text { パイプの外径 } & (\mathrm{mm}) \\ \alpha & =\text { 成形角度 (ス角 }) & (\mathrm{mm}) \\ S_{P} & =\text { スパイラルピッチ } & \left({ }^{\circ}\right) \\ S_{L} & =\text { スパイラルの長さ } & (1 \text { ピッチ当りの } \\ & \text { スパイラルの長さ) } & (\mathrm{mm}) \\ V_{B}=\text { ストリップの速度 } & (\mathrm{m} / \mathrm{min}) \\ V_{P}=\text { パイプの速度 } & (\mathrm{m} / \mathrm{min}) \\ V_{S}= & (\mathrm{m} / \mathrm{min})\end{array}$
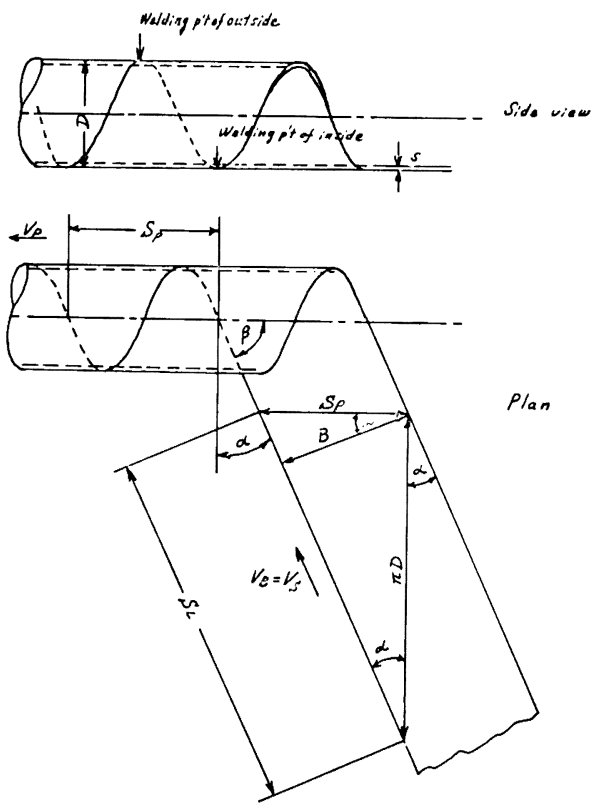

Fig. 1. View of spiral pipe forming.

$\beta=$ 傾斜角（スパイラル角）

関係式 :

$$
\begin{aligned}
\sin \alpha & =\frac{B}{\pi \cdot D} \ldots \ldots \ldots \ldots \ldots \ldots \ldots \ldots \ldots \\
S_{P} & =\frac{B}{\cos \alpha}=\pi D \tan \alpha
\end{aligned}
$$

* 昭和52年 4 月本会講演大会にて発表 昭和52年 4 月 18日受付 (Received April 18，1977)

** 住金大径鋼管(株) (Sumikin Weld. Pipe Company, Ltd., 2 Dejimanishi-machi Sakai Ōosaka 590) 


$$
\begin{aligned}
S_{L} & =\sqrt{S_{P}{ }^{2}+(\pi \cdot D)^{2}} \\
V_{P} & =V_{P} \cdot \sin \alpha \cdots \cdots \\
\frac{1}{B^{2}} & =\frac{1}{(\pi \cdot D)^{2}}+\frac{1}{S_{P^{2}}}
\end{aligned}
$$

\section{3. スパイラル鋼管の成形の解析}

スパイラル鋼管の成形がスパイラル造管の基本作業で あるゆえにこれを解析して見る.

この解析の出発点はストリップ(コイル)を Fig. 2 の ごとく 3 つのゾーンに分けて考えて見た.なぜならばこ れらのゾーンの成形プロセスが異なつているからであ る.

1) Aゾーンは a 点において，Gゾーンの成形された 部分と接触し，その直後で溶接され，その後はCゾーン の成形された部分と結合することによつて，Aゾーン自

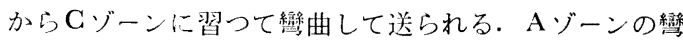
曲は 3-ロールベンデングのロールの助けを全然受けて

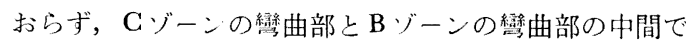
進えでいる状態である.

悸曲の大きいものと彎曲の小さいものとを溶接結合し て送り出寸場合，お互が干渉し合つて，それぞれの形に

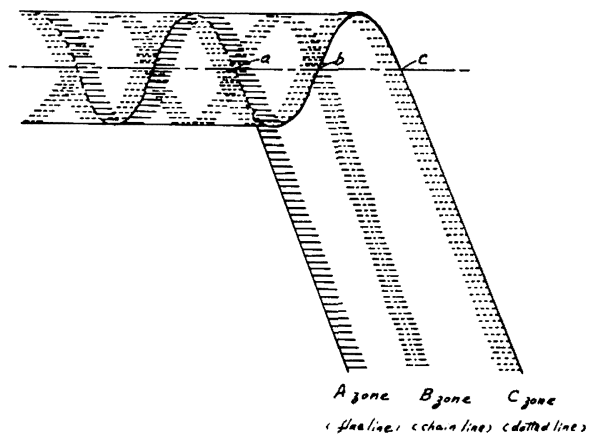

Fig. 2. Course of separated zone A, B and C.

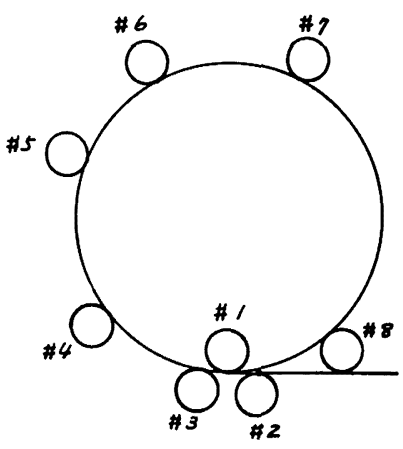

Fig. 3. Arrangement of guide rollers.
おける変形抵抗に反比例して変形し，(この場合双方と も加熱されているので変形抵抗值は低くなつている）溶 接結合が破れることなく進むのである.

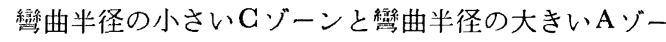
ンとが結合してできた彎曲半径は当然 Aゾーンの彎曲半

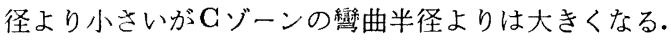

また C， Aゾーンの結合部は体積一定の法則で面積の 変化を余儀なくされた場合は厚さの変化で補なうことに なる.これがピーキングの現象として現われるのであ る.

2) B Bゾーンは b 点にて 3-ロールベンデングによつ て㴚曲され，その後成形ガイドロールによつてスプリン グバックで緊定されながら進んでいるので， 3 つのゾー ンの中で最も有利に成形されているゾーンである.

3） Gゾーンは c 点にて 3-ロールベンデングによつて 縞曲され，その後 \#4，\#5 のガイドロールによつてス プリングバックで緊定されるが最後のガイドロール（ 5 ) を離れてから最下位線 c - b - a の線に到達する距 㕵がBゾーンに比べて長いゆえにそれだけスプリングバ

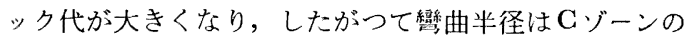
方がBゾーンに比して大きい.

$\Lambda, \mathrm{B}, \mathrm{C}$ のゾーンの彎曲半径（曲率半径）を比較す ると,

$$
\mathrm{A}>\mathrm{C}>\mathrm{B} \text { となる. }
$$

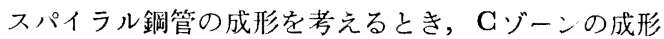
が最も重要である.

Gゾーンの成形を完壁にするため，このゾーンに関与 するガイドロールの最後のものの位置をできるだけ最下 位線に近づけるようにしなければならない。

\section{4. 成形におけるカについて}

当社の大径パイプの成形はすべて 3-ロールベンデン グ方式である.しかしスパイラルパイプとストレートシ 一ムパイプとは力の挙動が異なる.

Fig. 4 と Fig. 5 とを比較すると動きの源が異なつて いる. Fig. 4 は $\sharp 2$ と $\sharp 3$ ロールが動きの源であるが Fig. 5 はプレートが動きの源となつている. 力の方程式として次の式がある.

$$
P_{1}=\frac{C_{1} \cdot B \cdot S^{2} \cdot \sigma_{y}}{l}
$$

ここで :

$P_{1} \cdots \cdots \Downarrow 1$ ロールの力

$B \cdots \cdots$ プレート（ストリップ）の幅

$$
\text { もしくはスパイラルピッチ }
$$

$S \cdots \cdots$... プレート (ストリップ) の厚さ

( $\mathrm{mm}$ ) 


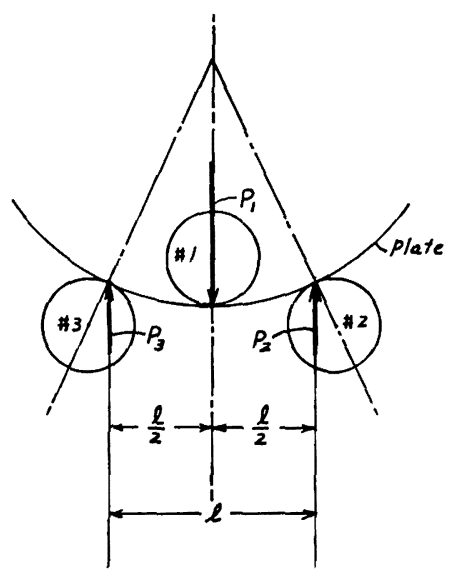

\#1-roll...............idle

\# 2, 3-roll..........drive

plate.................driven by rolls

Fig. 4. Pyramid type bending rolls for straight seam pipe.

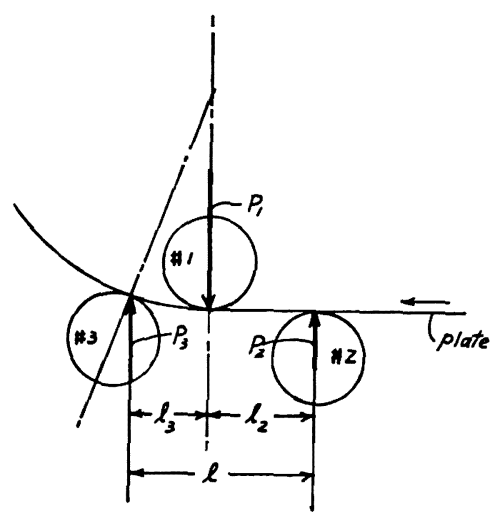

\# 1, 2, \& 3 roll..........idle

Fig. 5. 3 rolls bending for spiral seam pipe.

$l \cdots \cdots . \# 2, \# 3$ ロールとストリップとの

接点間の距離

$(\mathrm{mm})$

$\sigma_{y} \cdots \cdots$ ストリップの降伏点

$\left(\mathrm{kg} / \mathrm{mm}^{2}\right)$

$C_{1} \cdots \cdots$ 係数

$P_{2}=\frac{P_{1} l_{3}}{l}$

$P_{3}=\frac{P_{1} l}{l}$

以上の諸式で各ロールの力を算出することができる． スパイラルパイプの場合を更に詳細に検討して見る。

(Fig. 6 参照)

$F \cdot \cdots \cdot$. ストリップを送る力

$f_{1}, f_{2}, f_{3}$ は $\sharp 1, \sharp 2, \sharp 3$ ロールがストリップの送

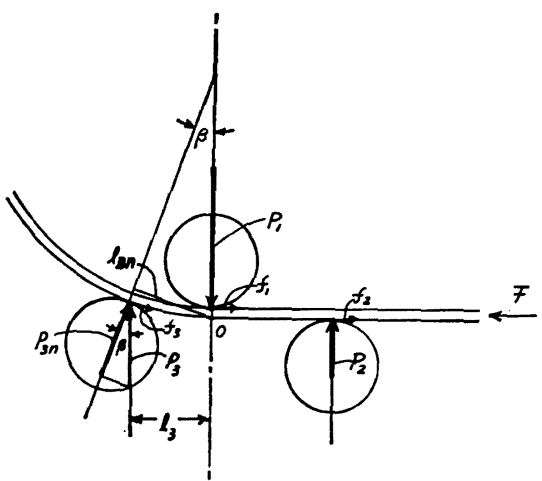

Fig. 6. Diagram of forces working on forming.

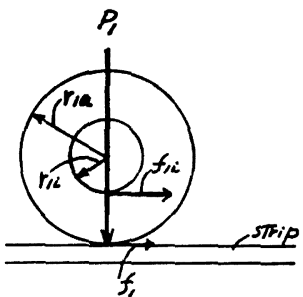

$r_{1 \mathrm{a}} \cdots \cdots . \# 1$ rolls outside radius

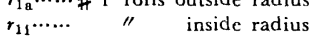

$f_{11} \cdots \cdots$.... friction between roll and axis

$f_{1} \cdots$....resistant force of \# 1 roll to strip's feeding

Fig. 7. Details of $\sharp 1$ roll.

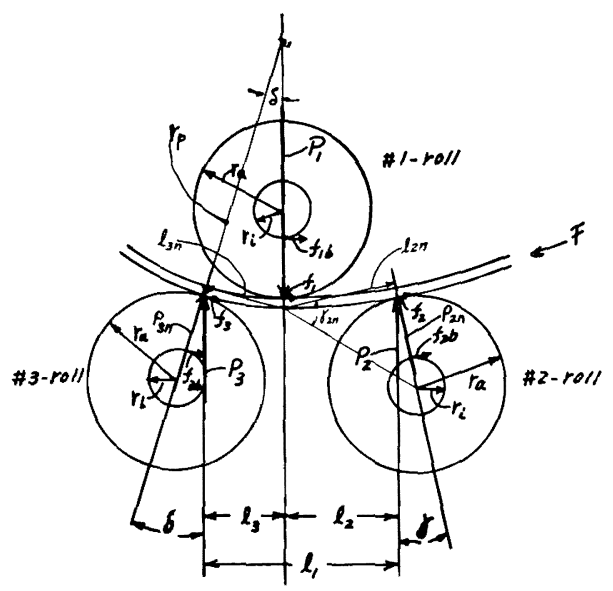

Fig. 8 . 3 rolls bending.

りに対する抵抗。

$P_{3 n}$ は鰵曲モーメントを等しくして $\sharp 3$ ロールをスト リップに垂直に作用させた場合の力.

1) \#1ロールにおいて (Fig. 7 参照)

$f_{1} \cdot r_{1 a}=f_{1 i} \cdot 1 i \quad$ (ロールの中心に対してのモーメン トを考えると） 


$$
\begin{aligned}
& f_{1}=f_{1 i} \cdot \frac{r_{1 i}}{r_{1 a}} \\
& f_{1 i}=\mu_{1} \cdot P_{1} \quad\left(\mu_{1} \cdots \cdots \text { 回転摩擦係数 }\right) \\
& f_{1}=\frac{\mu_{1} \cdot P_{1} \cdot r_{1 i}}{r_{1} a}
\end{aligned}
$$

2) $\$ 2$ ロールにおいて

$f_{2}=\mu_{2} \cdot P_{2} \cdot K \cdot \frac{r_{2 i}}{r_{2} a}$

$K=f(\alpha)$ すなわち $\alpha$ の函数であり設備の機楧 によつて決まる。

もし $r=\mathrm{O}$ の場合は

$$
f_{2}=\mu_{2} \cdot P_{2} \cdot \frac{r_{2 i}}{r_{2 a}} \text { となる. }
$$

3) \#3ロールにおいて

$$
\begin{aligned}
& P_{3} \times l_{3}=P_{3 n} \times l_{3 n} \\
& P_{3 n}=P_{3} \times \frac{l_{3}}{l_{3 n}}=P_{3} \times \frac{l_{3}}{r_{P} \sin \delta} \quad\left(r_{P} \ldots \ldots\right. \text { パイプの }
\end{aligned}
$$

半径)

$$
f_{3}=\frac{\mu_{3} \cdot P_{3} \cdot l_{3}}{r_{P} \sin \delta} \times \frac{r_{3 i}}{r_{36}}
$$

ゆえに $\$ 1 ， \sharp 2 ， \# 3$ のロールによつてのストリップ の送りに対する抵抗は

$$
\begin{aligned}
F_{\mathrm{b} 1-3} & =\frac{\mu_{1} \cdot P_{1} \cdot r_{1 i}}{r_{1 a}}+\frac{\mu_{2} \cdot P_{2} \cdot K \cdot r_{2 i}}{r_{23}} \\
& +\frac{\mu_{3} \cdot P_{3} \cdot l_{3} \cdot r_{3 i}}{r_{P} \sin \delta \cdot r_{3}} \ldots \ldots \ldots \ldots \ldots \ldots \ldots \ldots \ldots \ldots \ldots
\end{aligned}
$$

\section{3 ロールによる継曲成形に おけるカについて}

3ーロールで物体を彎曲する場合は中央に働く力の方向

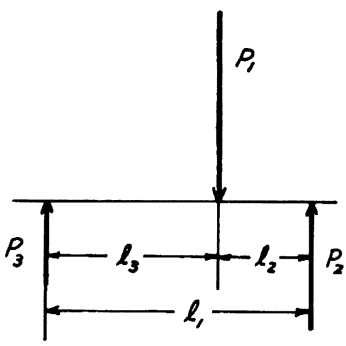

Fig. 9. Relation between bending forces.

Table 1. Values of $C_{2}$.

\begin{tabular}{ccc|c}
\hline$l_{2}$ & $:$ & $l_{3}$ & $C_{2}$ \\
\hline 1 & $:$ & 1 & 4 \\
1 & $\vdots$ & 2 & 5.5 \\
1 & $\vdots$ & 3 & 5.3 \\
1 & $:$ & 4 & 7.2 \\
\hline
\end{tabular}

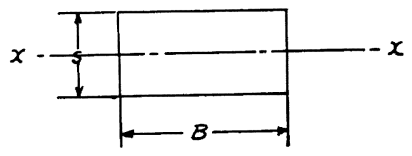

Fig. 10. Size of section.

は両側に働く力の方向と相反することが必要である.そ の場合の条件は次のごとくである.

$$
P_{1}=P_{2}+P_{3}, \quad l_{1}=l_{2}+l_{3}
$$

$M$ を曲げモーメントとすると

$$
\begin{aligned}
& M=P_{2} l_{2}=P_{3} l_{3} \\
& M=\frac{P_{1} l_{1}}{C_{2}} \quad \text { とした場合の } C_{2} \text { の值は } l_{2}: l_{3} \text { の }
\end{aligned}
$$

比によつて Table 1 のごとくに変わる.

$\sigma_{b} \cdots \cdots$ 最大曲げ応力

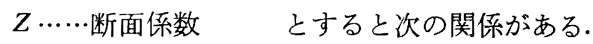

（ただし弾性限界において）

$$
\sigma_{b}=\frac{M}{Z}
$$

断面が Fig. 10 の場合は

断面係数 $Z=\frac{1}{6} B s^{2}$ となるゆえに

$\sigma_{b}=\frac{P_{1} l_{1}}{C_{2}} \cdot \frac{6}{B s^{2}}$, 更に

$P_{1}=\frac{C^{2} / 6 \cdot \sigma_{b} \cdot B \cdot s^{2}}{l}$ と変形される.

蟹曲变形をする場合は $\sigma_{b}$ は塑性变形応力であるゆえ に降伏点 $\sigma_{y}$ よりも大きい. 今 $\sigma_{b}=1.2 \sigma_{y}$ および $C_{2}=$ 4 を採用すると $P_{1}=\frac{4 / 6 \times 1.2 \sigma_{y} \cdot B \cdot s^{2}}{l_{1}}=\frac{0.8 \sigma_{y} \cdot B s^{2}}{l_{1}}$ と なり，更に降伏点の上限および $l_{2}: l_{3}$ を考え安全率と

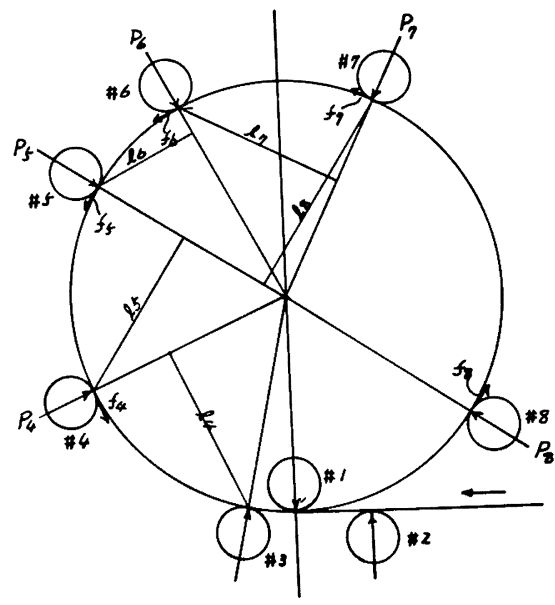

Fig. 11. Arrangement of guide rolls. 


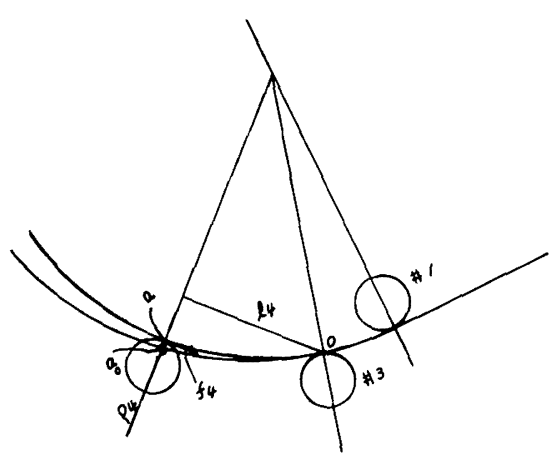

Fig. 12. Comparing the cource of strip guided by guide roll with that without it.

して 1.5 を用いると $(1.5 \times 0.8=1.2)$ 次のごとき式と なる.

$$
P_{1}=\frac{1.2 \sigma_{y} \cdot B \cdot s^{2}}{l_{1}}
$$

スパイラルパイプの場合は $B$ の代りに $\frac{B}{\cos \alpha}$ のスパイ ラルピッチを用いなければならないが $l_{1}$ も $\frac{l_{1}}{\cos \alpha}$ を用 いることになるので結局同じ式である.

\section{6. 成形外周ガイドロールのカについて}

成形外周ガイドロール \#8 について検討して見る. (Fig. 11 参照)

各ロールのストリップに対する法線を $P_{4}, P_{5}, P_{6} \ldots \ldots$ $P_{n}$ とし,

各ロールの法線力に対し，その前のロールにおけるス トリップ接点からの垂直距離を $l_{4}, l_{5}, l_{6} \cdots \cdots l_{n}$ とする. 今 \#4ロールの場合を取りあげて見る. (Fig. 12 参照) \#3 ロールを離れたストリップは たときは O-a 0 のコースを通り，\#4 ロールが働いたと きは O-a のコースを通る. \#4 ロールによつてストリ ップは O- $\mathrm{a}_{0}$ から O-a に曲げられることになる。した がつてこれに必要な力 $P_{4}$ が働いているのである．この 場合の $\mathrm{O}$ 点に対するモーメントは $M_{4}=P_{4} \times l_{4}$ である. この場合は弾性限界の作用であるゆえに次の式が用いら れる.

$$
\begin{aligned}
& \sigma=\frac{M}{Z} \\
& \text { ここにおいて } \quad \sigma \cdots \cdots \text { 内部応力 } \quad\left(\mathrm{kg} / \mathrm{mm}^{2}\right) \\
& M \cdots \cdots \cdot \text { 曲げモーメント }(\mathrm{kg} \cdot \mathrm{mm}) \\
& Z \text { …...率面係数 }
\end{aligned}
$$$$
\text { ゆえに } \quad \sigma=\frac{P_{4} \cdot l_{4}}{Z}
$$

$$
P_{4}=\frac{\sigma \cdot Z}{l_{4}}
$$

ここにおいて $\sigma$ は応力-正一線図から判るごとく，雪に 比例するものである.すなわち曲げ程度で变つてくる.

ストリップの送りに対する抵抗は

$$
\begin{aligned}
& f_{4}=\frac{\mu_{4} \cdot P_{4} \cdot r_{4 i}}{r_{4}} \\
& \text { ここにおいて } \\
& \mu_{4} \cdots \cdots . . .4 \text { 口ールの内面の摩擦係数 } \\
& r_{4 a} \cdots \cdots+\cdots 4 \text { 口ールの半径 } \\
& r_{4 i} \cdots \cdots . \cdots 4 \text { ロールの軸受けの半径 }
\end{aligned}
$$

以上の (14), (15) 式を一般化すると次のごとくにな る.

$$
\begin{aligned}
& P_{n}=\frac{\sigma_{n} \cdot Z}{l_{n}} \ldots \ldots \\
& f_{n}=\frac{\mu_{n} \cdot P_{n} \cdot r_{n i}}{r_{n a}}
\end{aligned}
$$

成形ガイドロールの全抵抗は，

$$
F_{g \cdot r \cdot}=f_{4}+f_{5}+f_{6}+f_{7}+f_{8}=\sum_{4}^{n} f_{n}
$$

計算並びにガイドロールの調整について考虑すべき事 項.

$\sigma_{4}$ は $\sharp 4$ ロールの曲げ量から決定し, 以後の $\sigma_{n}$ は $\sigma_{4}$ の值を採用して差支えない。なぜならば常に弾性限 界の変形で作用しているからである. 各ガイドロールを 離れるとスプリングバックして元の曲り姿になる.これ が成形に打ける残留応力と言われているものである. 彷 つて 3ロールベンデングにおいて が正規のパイプの円周の円弧からどれだけずれているか ということがスプリングバックの大きさとなる，また \# 4 ロールにおいて弾性限界を越えて変形をするときは, その際の $\sigma_{4}$ 浲伏点を越えた值である.

スプリングバック（成形残留応力）をなくすためには いかにすべきか、。

1) 3 ロールベンデングでスプリングバックを考虑し て正規のパイプ円周の円弧より若千小さく成形するこ ¿.

2) 最後のガイドロールの位置はできるだけ溶接点に 近つけること.

\section{7. ドライビングロール自体の抵抗について}

Fig. 13 参照

$$
\begin{gathered}
P_{u} \cdots \cdots \text { 上ロールの一方の軸受にかかる力 } \\
P_{l} \cdots \cdots \text { 下ロールの一方の軸受にかかる力 } \\
\quad=P_{u}+W(\text { ロール } 1 \text { ケの重量 }) \\
f_{u} \cdots \cdots \text { 上軸受における抵抗 }
\end{gathered}
$$



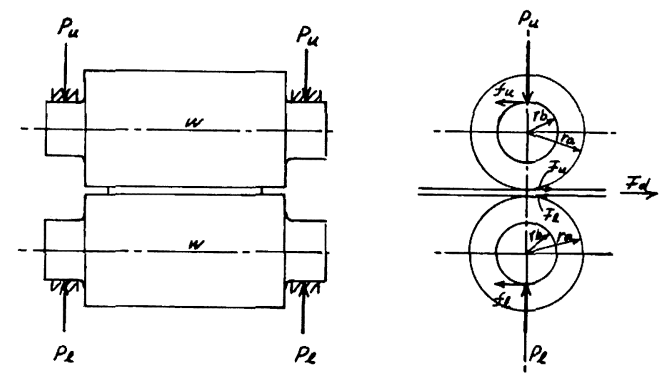

Fig. 13. Resistance of driving roll itself.

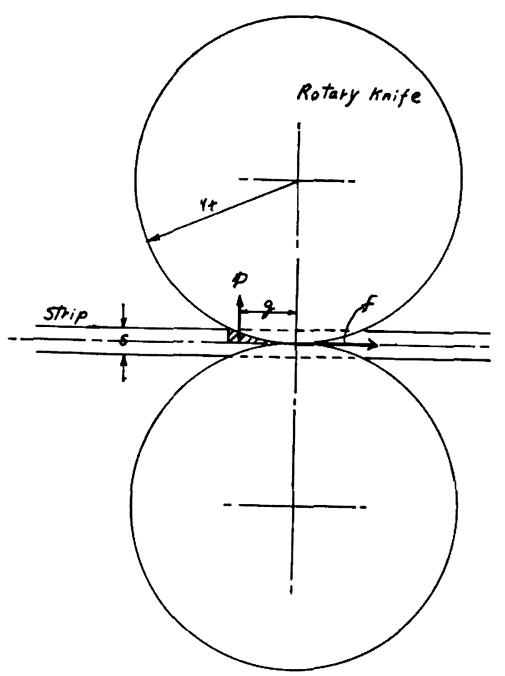

Fig. 14. Side Trimmer.

$=\mu \cdot P_{u}, （ \mu \cdots$ 回転摩擦係数 $)$

$f_{l} \cdots \cdots$ 下軸受における抵抗

$=\mu \cdot P_{l}$

ロール中心線に対するメントを考え時，上ロールの抵 抗と上軸受の抵抗との関係は次のごとくである.

$$
\begin{aligned}
& F_{u} \times r_{a}=f_{u} \times r_{b} \\
& F_{u}=f_{u} \times \frac{r_{b}}{r_{a}}
\end{aligned}
$$

同様に下ロールの抵抗と下軸受の抵抗との関係は

$$
\begin{aligned}
& F_{l} \times r_{a}=f_{l} \times r_{b} \\
& F_{l}=f_{l} \times \frac{r_{b}}{r_{a}}
\end{aligned}
$$

ドライビングロールの全抵抗は次式になる.

$$
F_{d}=2 \times\left(F_{u}+F_{l}\right)=2 \times \mu\left(2 P_{u}+W\right) \times \frac{r_{b}}{r_{a}} . .
$$

\section{8. サイドトリンマーのカについて}

Fig. 14 参照 $f_{t} \cdots \cdots$ サイドトリンマーナイフの半径

$s \cdots \cdots$ ストリップの厚さ

$p \cdot \cdots \cdot 1$ つのナイフにかかる剪断抵抗力

$f \cdots \cdots 1$ つのナイフにかかる引張力

$g$......萁断抵抗力の重心とナイフの

$$
\text { 中心線との距離 }
$$

1つのナイフのモーメントを取り扱かつて見ると次の 関係がある.

$$
f \cdot r_{t}=p \cdot g
$$

$$
p=\tau \cdot a
$$

ここにおいて,

$$
\tau \text { ……剪断応力 } \quad\left(\mathrm{kg} / \mathrm{mm}^{2}\right)
$$$$
a \text { ……剪断応力が働いている面積 }\left(\mathrm{mm}^{2}\right)
$$

Fig. 15 において

b c d の三日月の面積

$$
=1 / 2\left\{r_{t}(l-2 h)+2 h \times s / 2\right\}
$$

$l \cdots . .$. 弧 $\mathrm{b} \mathrm{c} \mathrm{d}$ の長さ

$$
=2 \pi r_{t} \times \frac{2 \times \sin ^{-1} \cdot h / r_{t}}{360^{\circ}}
$$

$h+. . .$. 弦 $\mathrm{b} \mathrm{d}$ の半分

$$
=\sqrt{\left(2 r_{t}-s / 2\right) \times s / 2}
$$

したがつて

$$
a=h \cdot s / 2-1 / 4\left\{r_{t}(l-2 h)+2 h \times s / 2\right\}
$$

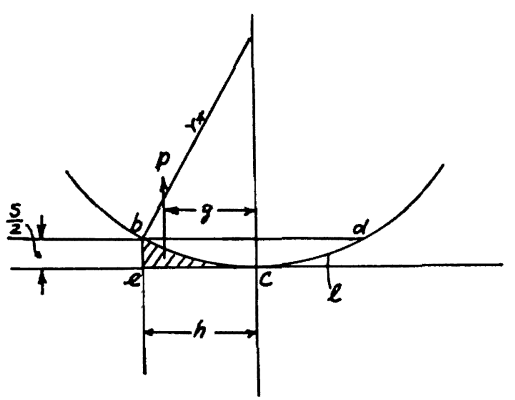

Fig. 15. Detail of trimming section.

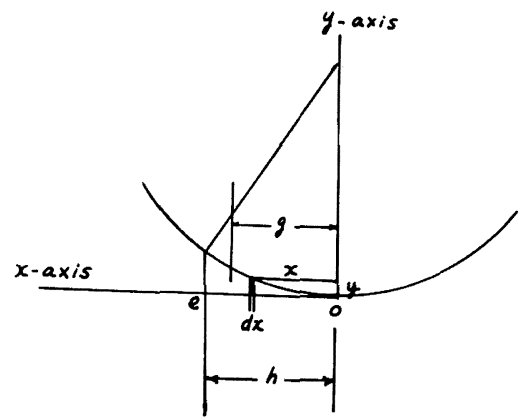

Fig. 16. $x-y$ coordinate. 
Fig. 16 に㧍いて $g$ は次の式で表わされる.

$$
g=\frac{\int_{0}^{h} x y d x}{\int_{0}^{h} y d x}
$$

$x, y$ の関係を考えて見ると

$$
\begin{aligned}
& x^{2}=\left(2 r_{t}-y\right) y \\
& y^{2}-2 r_{t} y+x^{2}=0 \\
& y=\frac{2 r_{t} \pm \sqrt{4 r_{t}^{2}-4 x^{2}}}{2}
\end{aligned}
$$

$y$ は $r_{t}$ より小さいゆえに（一）の符号のみ採用する.

$$
\begin{gathered}
y=\frac{2 r_{t}-\sqrt{4 r_{t}^{2}-4 x^{2}}}{2} \\
\int_{0}^{h} x y d x=\int_{0}^{h} \frac{2 r_{t}-\sqrt{4 r_{t}^{2}-4 x^{2}}}{2} \cdot x d x
\end{gathered}
$$

$2 r_{t}=K$ を代入すると

$$
\begin{aligned}
& =\int_{0}^{h} \frac{K-\sqrt{K^{2}-4 x^{2}}}{2} \cdot x d x \\
& =\int_{0}^{h} \frac{K}{2} \cdot x d x-\int_{0}^{h} \frac{\sqrt{K^{2}-4 x^{2}}}{2} \cdot x d x
\end{aligned}
$$$$
\int_{0}^{h} \frac{K}{2} \cdot x d x=\left[\frac{K x^{2}}{4}\right]_{0}^{h}=\left[\frac{2 r_{t} x^{2}}{2}\right]_{0}^{h}=\left[\frac{r_{t} x^{2}}{2}\right]_{0}^{h}=\frac{r_{t} h^{2}}{2}
$$$$
\int \frac{\sqrt{K^{2}-4 x^{2}}}{2} \cdot x d x=\int_{0}^{h} \frac{\sqrt{K^{2}-4 x^{2}}}{4} d x^{2}
$$$$
=\int_{0}^{h} \frac{\sqrt{K^{2}-4 x^{2}}}{16} \cdot d 4 x^{2}
$$

$4 x^{2}=b$ を代入すると

$$
=\int \frac{\sqrt{K^{2}-b}}{16} d b=\int-\frac{\sqrt{K^{2}-b}}{16} d\left(K^{2}-b\right)
$$

$$
K^{2}-b=n \text { を代入すると }
$$

$$
\begin{aligned}
= & -\int \frac{\sqrt{n}}{16} d n=-\frac{1}{16} \int n^{1 / 2} \cdot d n=-\frac{1}{16}\left[\frac{n^{3 / 2}}{3 / 2}\right] \\
= & -\left[\frac{1}{24} n^{3 / 2}\right]
\end{aligned}
$$

$n=K^{2}-b$ と還元すると

$$
=-\frac{1}{24}\left[\left(K^{2}-b\right)^{3 / 2}\right]
$$

$b=4 x^{2}$ と還元すると

$$
=-\frac{1}{24}\left[\left(K^{2}-4 x^{2}\right)^{3 / 2}\right]_{0}^{h}
$$

$K=2 r_{t}$ と還元すると

$$
\begin{array}{rl} 
& =-\frac{1}{24}\left[\left(4 r_{t}^{2}-4 x^{2}\right)^{3 / 2}\right]_{0}^{h} \\
\int_{0}^{h} & x y d x=\left[\frac{r_{t} x^{2}}{2}\right]_{0}^{h}+\left[\frac{1}{24}\left(4 r_{t}-4 x^{2}\right)^{3 / 2}\right]_{0}^{h} \\
& =\frac{r_{t} h^{2}}{2}+\left\{\frac{1}{24}\left(4 r_{t}^{2}-4 h^{2}\right)^{3 / 2}\right\}-\left\{\frac{1}{24}\left(4 r_{t}^{2}\right)^{3 / 2}\right\}
\end{array}
$$$$
\int_{0}^{h} y d x=\int_{0}^{h} \frac{2 r_{t}-\sqrt{4 r_{t}^{2}-4 x^{2}}}{2} \cdot d x
$$

\begin{tabular}{|c|c|c|c|c|c|c|c|}
\hline$r_{t}(\mathrm{~mm})$ & $S(\mathrm{~mm})$ & $a\left(\mathrm{~mm}^{2}\right)$ & $\tau\left(\mathrm{kg} / \mathrm{mm}^{2}\right)$ & $p(\mathrm{~kg})$ & $g(\mathrm{~mm})$ & $f(\mathrm{~kg})$ & $F_{S}(\mathrm{~kg})$ \\
\hline $\begin{array}{l}250 \\
" 1 \\
" 1 \\
" 1 \\
200 \\
" 1 \\
" 1 \\
" 1\end{array}$ & $\begin{array}{l}10 \\
12 \\
15 \\
19 \\
22 \\
10 \\
12 \\
15 \\
19 \\
22\end{array}$ & $\begin{array}{r}156 \\
165 \\
185 \\
220 \\
303 \\
77 \\
100 \\
137 \\
190 \\
265\end{array}$ & $\begin{array}{l}35 \\
\text { " } \\
\text { " } \\
\text { " } \\
\text { " } \\
\text { " } \\
\text { " } \\
\text { ", }\end{array}$ & $\begin{array}{r}5460 \\
5775 \\
6475 \\
7700 \\
10605 \\
2695 \\
3500 \\
4795 \\
6650 \\
9275\end{array}$ & $\begin{array}{l}19 \\
25.5 \\
33.5 \\
42 \\
48 \\
31.5 \\
35 \\
39.5 \\
45.6 \\
49.2\end{array}$ & $\begin{aligned} & 414.9 \\
& 589.05 \\
& 867.65 \\
& 1293.6 \\
& 2036.16 \\
& \quad 424.46 \\
& 612.5 \\
& 947.01 \\
& 1516.2 \\
& 2281.6\end{aligned}$ & $\begin{array}{ll}1 & 659.8 \\
2 & 356.2 \\
3 & 470.6 \\
5 & 174.4 \\
8 & 144.6 \\
1 & 697.8 \\
2 & 450.0 \\
3 & 788.05 \\
6 & 064.8 \\
9 & 126.6\end{array}$ \\
\hline
\end{tabular}$$
=\int_{0}^{h} r_{t} d x-\int_{0}^{h} \frac{\sqrt{4 r_{t}^{2}-4 x^{2}}}{2} \cdot d x
$$$$
=\left[r_{t} \cdot x\right]_{0}^{h}-\int_{0}^{h} \sqrt{r_{t}^{2}-x^{2} \cdot d x}
$$$$
=\left[r_{t} \cdot \mathrm{x}\right]_{0}^{h}-\left[\frac{x}{2} \sqrt{r_{t}{ }^{2}-x^{2}}+\frac{r_{t}{ }^{2}}{2} \cdot \frac{\pi}{180} \sin ^{-1} \frac{x}{r_{t}}\right]_{0}^{h}
$$$$
=r_{t} \cdot h-\frac{h}{2} \sqrt{r_{t}^{2}-h^{2}}-\frac{r_{t}^{2}}{2} \sin -1 \frac{h}{r_{t}}
$$

したがつて

$$
\begin{aligned}
g= & \frac{\int_{0}^{h} x y d x}{\int_{0}^{h} y d x} \\
& =\frac{\frac{r_{t} \cdot h^{2}}{2}+\left\{\frac{1}{24}\left(4 r_{t}^{2}-4 h^{2}\right)^{3 / 2}\right\}-\frac{1}{24}\left(4 r_{t}^{2}\right)^{3 / 2}}{r_{t} \cdot h-\frac{h}{2} \sqrt{r_{t}^{2}-h^{2}}-\frac{r_{t}^{2}}{2} \cdot \frac{\pi}{180} \cdot \sin -1 \frac{h}{r_{t}}}
\end{aligned}
$$

$$
f=\frac{\tau \cdot a \cdot g}{r_{t}}
$$

サイドトリンマーに要する全引張力 (抵抗) は次式のご とくになる.

$$
F_{S}=4 f
$$

ナイフの半径 $r_{t}=250 \mathrm{~mm}$ および $200 \mathrm{~mm}$ の場合の ストリップ各厚さに対しての $p$ および $F_{S}$ を算出し

Table 2. Calculated values. 


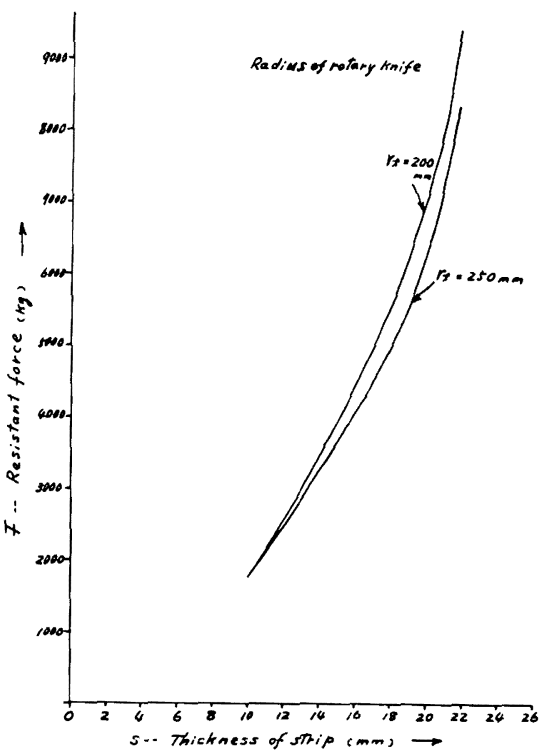

Fig. 17. Resistant force of side trimmer.

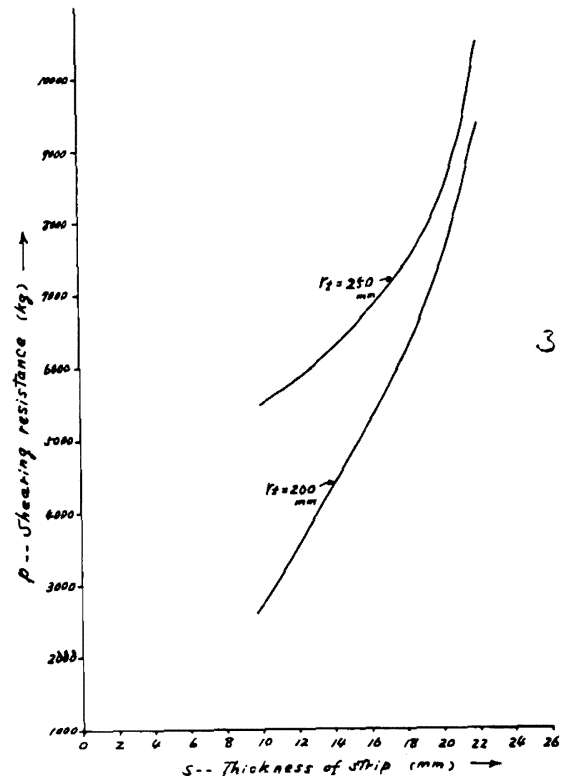

Fig. 18. Shearing resistance of side trimmer.

Table 2 ならびに Fig. 17, 18 に示した.

図から判明することはナイフの径の大きいちがサイド トリンマーの抵抗としては小さいということである.た だしサイドトリンマー自体には大きな力がかかつてい る.

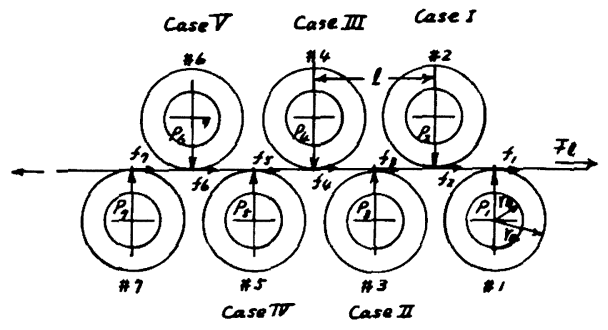

Fig. 19. Resistant force of leveller.

9.レベラーの抵抗について

Fig. 19 参照

Case I においては

$$
\begin{aligned}
& P_{1}=\frac{C_{1} \cdot \sigma \cdot B \cdot s^{2}}{2 l} \\
& P_{2}=\frac{C_{1} \cdot \sigma \cdot B \cdot s^{2}}{l} \\
& P_{3}=\frac{C_{1} \cdot \sigma \cdot B \cdot s^{2}}{2 l}
\end{aligned}
$$

Case IIにおいては

$$
\begin{aligned}
& P_{2}=\frac{C_{2} \cdot \sigma \cdot B \cdot s^{2}}{2 l} \\
& P_{3}=\frac{C_{2} \cdot \sigma \cdot B \cdot s^{2}}{l} \\
& P_{4}=\frac{C_{2} \cdot \sigma \cdot B \cdot s^{2}}{2 l}
\end{aligned}
$$

Case II⿰扌いては

$$
\begin{aligned}
& P_{3}=\frac{C_{3} \cdot \sigma \cdot B \cdot s^{2}}{2 l} \\
& P_{4}=\frac{C_{3} \cdot \sigma \cdot B \cdot s^{2}}{l} \\
& P_{5}=\frac{C_{3} \cdot \sigma \cdot B \cdot s^{2}}{2 l}
\end{aligned}
$$

Case IVにおいては

$$
\begin{aligned}
& P_{4}=\frac{C_{4} \cdot \sigma \cdot B \cdot s^{2}}{2 l} \\
& P_{5}=\frac{C_{4} \cdot \sigma \cdot B \cdot s^{2}}{l} \\
& P_{6}=\frac{C_{4} \cdot \sigma \cdot B \cdot s^{2}}{2 l}
\end{aligned}
$$

Case Vにおいては

$$
\begin{aligned}
& P_{5}=\frac{C_{5} \cdot \sigma \cdot B \cdot s^{2}}{2 l} \\
& P_{6}=\frac{C_{5} \cdot \sigma \cdot B \cdot s^{2}}{l} \\
& P_{7}=\frac{C_{5} \cdot \sigma \cdot B \cdot s^{2}}{2 l}
\end{aligned}
$$




$$
\begin{aligned}
P_{1}= & \Sigma p_{1}=\frac{C_{1} \cdot \sigma \cdot B \cdot s^{2}}{2 l}=\frac{\sigma \cdot B \cdot s^{2}}{l}\left(\frac{C_{1}}{2}\right) \\
P_{2}= & \Sigma p_{2}=\frac{C_{1} \cdot \sigma \cdot B \cdot s^{2}}{l}+\frac{C_{2} \cdot \sigma \cdot B \cdot s^{2}}{2 l}=\frac{\sigma \cdot B \cdot s^{2}}{l}\left(C_{1}+\frac{C_{2}}{2}\right) \\
P_{3}= & \Sigma p_{3}=\frac{C_{1} \cdot \sigma \cdot B \cdot s^{2}}{2 l}+\frac{C_{2} \cdot \sigma \cdot B \cdot s^{2}}{l}+\frac{C_{3} \cdot \sigma \cdot B \cdot s^{2}}{2 l} \\
= & \frac{\sigma \cdot B \cdot s^{2}}{l}\left(\frac{C_{1}}{2}+C_{2}+\frac{C_{3}}{2}\right) \\
P_{4}= & \Sigma p_{4}=\frac{C_{2} \cdot \sigma \cdot B \cdot s^{2}}{2 l}+\frac{C_{3} \cdot \sigma \cdot B \cdot s^{2}}{l}+\frac{C_{4} \cdot \sigma \cdot B \cdot s^{2}}{2 l} \\
= & \frac{\sigma \cdot B \cdot s^{2}}{l}\left(\frac{C_{2}}{2}+C_{3}+\frac{C_{4}}{2}\right) \\
P_{5}= & \sum p_{5}=\frac{C_{3} \cdot \sigma \cdot B \cdot s^{2}}{2 l}+\frac{C_{4} \cdot \sigma \cdot B \cdot s^{2}}{l}+\frac{C_{4} \cdot \sigma \cdot B \cdot s^{2}}{2 l} \\
= & \frac{\sigma \cdot B \cdot s^{2}}{l}\left(\frac{C_{3}}{2}+C_{4}+\frac{C_{5}}{2}\right) \\
P_{6}= & \Sigma p_{6}=\frac{C_{4} \cdot \sigma \cdot B \cdot s^{2}}{2 l}+\frac{C_{5} \cdot \sigma \cdot B \cdot s^{2}}{l}=\frac{\sigma \cdot B \cdot s^{2}}{l}\left(\frac{C_{4}}{2}+C_{5}\right) \\
P_{7}= & \Sigma p_{7}=\frac{C_{5} \cdot \sigma \cdot B \cdot s^{2}}{2 l}=\frac{\sigma \cdot B \cdot s^{2}}{l}\left(\frac{C_{5}}{2}\right) \\
\Sigma &
\end{aligned}
$$

各ロールの抵抗は次の式のとおりになる.

$$
\begin{aligned}
& f_{1}=\mu \cdot \frac{r_{i}}{r_{a}} \cdot P_{1} \\
& f_{2}=\mu \cdot \frac{r_{i}}{r_{a}} \cdot P_{2} \\
& f_{3}=\mu \cdot \frac{r_{i}}{r_{a}} \cdot P_{3} \\
& f_{4}=\mu \cdot \frac{r_{i}}{r_{a}} \cdot P_{4} \\
& f_{5}=\mu \cdot \frac{r_{i}}{r_{a}} \cdot P_{5} \\
& f_{6}=\mu \cdot \frac{r_{i}}{r_{a}} \cdot P_{6} \\
& f_{7}=\mu \cdot \frac{r_{i}}{r_{a}} \cdot P_{7}
\end{aligned}
$$

レベラーの全抵抗は次のとおりである.

$F_{l}=f_{1}+f_{2}+f_{3}+f_{4}+f_{5}+f_{6}+f_{7}$

\section{0. アンコイラーの抵抗について}

Fig. 20 参照

$$
\begin{aligned}
& G_{C} \cdots \cdots \cdot \text { ・ルルの重量 } \\
& g_{m} \cdots \cdots \text {...マントレルの重量 } \\
& g_{p} \cdots \cdots \text {....ンンドレル軸押え力 } \\
& r_{u} \cdot c \cdot \cdots \text { マ・ントレル軸の半径 } \\
& { }^{r} \text { ……コイルの半径 } \\
& G=G_{C}+g_{m}+2 \times g_{p}
\end{aligned}
$$

アンコイラーの抵抗は次の式のと打りとなる.

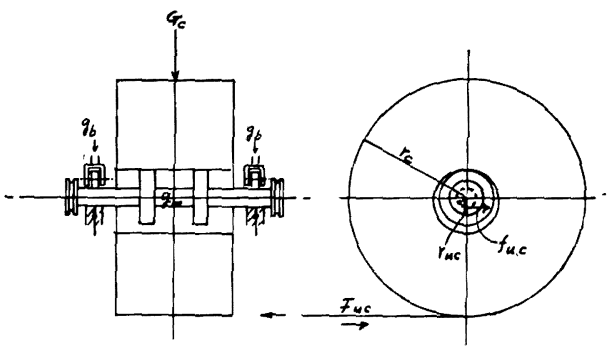

Fig. 20. Resistant force of uncoiler.

$$
F_{u \cdot C \cdot}=G \times \mu \times \frac{r_{u \cdot C}}{r_{C}}
$$

11. チアンファリングおよびベベリング

\section{の抵抗について}

チアンファリングの抵抗 $f_{C}$ は次式で算出する.

$$
f_{C}=q \cdot K_{S}
$$

ここにおいて

$$
\begin{array}{lr}
q \cdots \cdots \text { 切削面積 } & \left(\mathrm{mm}^{2}\right) \\
K_{S} \cdots \cdots \text { 比切削抵抗 } & \left(\mathrm{kg} / \mathrm{mm}^{2}\right)
\end{array}
$$

ベベリングの抵抗 $f_{b}$ は次式で算出する.

$$
f_{b}=q^{\prime} \cdot K_{S}^{\prime}
$$

ここにおいて

$$
\begin{aligned}
& q^{\prime} \cdots \cdots \cdot \text { 切削面積 } \\
& K_{S}^{\prime} \cdots \cdots \text { 比切削抵抗 }
\end{aligned}
$$

チアンファリングおよびベベリングの総抵抗は次式の ごとくになる.

$$
F_{C+b}=f_{C}+f_{b}
$$

\section{2. アゥトレットテーブルの抵抗について}

アウトレットテーブルの抵抗は次式のごとくである.

$$
F_{0}=G_{p} \cdot \mu \cdot \frac{r_{i}}{r_{a}} \cdot K_{1}
$$

ここにおいて

$$
\begin{gathered}
G_{p} \cdots \cdots \text { ア...トレットテーブル上の } \\
\text { パイプの重量 }
\end{gathered}
$$

$\mu \cdots \cdots$ 受けローラー軸の回転摩擦係数

$$
\begin{array}{cl}
r_{a} \cdots \cdots \cdot \text { 受けローラーの半径 } & (\mathrm{mm}) \\
r_{i} \cdots \cdots \cdot \text { 受けローラーの軸の半径 } & (\mathrm{mm}) \\
K_{1} \cdots \cdots \text { 受けローラーの位置に関する係数 } & \\
=\left(\sqrt{\frac{2}{3}}=1.51\right) &
\end{array}
$$

\section{3. 巻戾しの抵抗について}

曲げモーメント $\left(M_{b}\right)$ は 
$M_{b}=\frac{1.5 \times \sigma_{y} \times B \times s^{2}}{6} \quad(\mathrm{~kg} / \mathrm{mm})$

距離（ $l$ ) における押え力 $(f)$ は

$$
f=\frac{M_{b}}{l}
$$

巻戻し抵抗は次式となる。

$F$ 巻实し $=\mu \cdot f$

\section{4. 七ンターリングの抵抗}

センターリングの抵抗は次式のごとくになる.

$$
F_{\text {cent }}=f_{h} \cdot \mu \cdot \frac{r_{b}}{r_{r}} \cdot n
$$

ここにおいて

$$
\begin{aligned}
& f_{h} \cdots \cdots \text {...油任による押え力 } \\
& \mu \cdots \cdots \text { - } \\
& r_{b} \cdots \cdots \text {... } \\
& r_{r} \ldots \ldots \text {....ラーの半径 } \\
& n+\cdots \cdots \text { - }
\end{aligned}
$$

\section{5. サイドガイ ドの抵抗}

サイドガイドの抵抗は次式で計算する.

$$
F_{\text {side }}=f_{h} \cdot \mu \cdot \frac{r_{b}}{r_{r}} \cdot n
$$

記号は前項の解釈と同じである.

\section{6. プレベンデングの抵抗}

プレベンデングの抵抗は次式で計算する.

$$
F_{\mathrm{pb}}=f_{h} \cdot \mu \cdot \frac{r_{b}}{r_{r}} \cdot n
$$

記号は前項の解釈と同じである。

17. パイプの重量およびストリップの

\section{重量について}

造管機の主駆動モーターの重要な仕事はパイプとスト

\begin{tabular}{|c|c|c|c|c|c|c|}
\hline & \multicolumn{3}{|c|}{ Product's size (O. D. $\mathrm{mm} \times$ thickness $\mathrm{mm}$ ) } & $609.6 \times 14$ & $1016 \times 22$ & $711.2 \times 9.53$ \\
\hline & \multicolumn{3}{|c|}{ Material } & S T K 41 & S T K 41 & $\mathrm{STK} 41$ \\
\hline & \multicolumn{3}{|c|}{ Welding speed } & 0.03 & 0.017 & 0.0417 \\
\hline & \multicolumn{2}{|r|}{ Weight of coil } & $\mathrm{kg}$ & 16.340 & 23.000 & 23.000 \\
\hline$\mu$ & \multicolumn{3}{|c|}{ Length of product } & 7 & 12 & 12 \\
\hline \multirow[t]{4}{*}{$\begin{array}{l}0.05 \\
0.04 \\
0.04 \\
0.02\end{array}$} & $\begin{array}{l}(1) \\
(2) \\
(3) \\
(4) \\
(5) \\
(6) \\
(7) \\
(8) \\
(9) \\
(10) \\
(11) \\
(12) \\
(13)\end{array}$ & 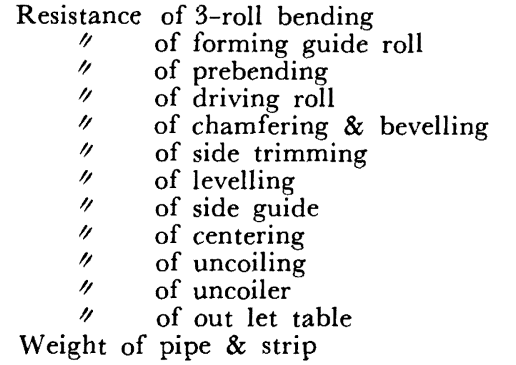 & 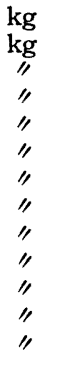 & $\begin{array}{r}756 \\
544 \\
6857 \\
1248 \\
3162 \\
3150 \\
9616 \\
720 \\
660 \\
170 \\
246 \\
361 \\
5952\end{array}$ & $\begin{array}{r}1222 \\
590 \\
6857 \\
1655 \\
9222 \\
8000 \\
23744 \\
720 \\
660 \\
420 \\
301 \\
1290 \\
16038\end{array}$ & $\begin{array}{r}841 \\
246 \\
6857 \\
1045 \\
1064 \\
1600 \\
5300 \\
720 \\
660 \\
94 \\
321 \\
389 \\
5719\end{array}$ \\
\hline & \multicolumn{2}{|r|}{ Sum total $※$} & " & 33.442 & 70.719 & 24.856 \\
\hline & \multicolumn{2}{|c|}{$\begin{array}{l}\text { Calculated current } \\
\quad \times \times \text { welding speed } \div 102.04 \times 1000 \div 440 \\
\text { No load current }\end{array}$} & imp & $\begin{array}{r}22.345 \\
7.2\end{array}$ & $\begin{array}{r}26.77 \\
4.0\end{array}$ & $\begin{array}{r}23.085 \\
10.0\end{array}$ \\
\hline & \multicolumn{2}{|c|}{$\begin{array}{l}\text { Current (calculaled) } \\
\text { Current (indicated) }\end{array}$} & imp & $\begin{array}{l}29.54 \\
35 .\end{array}$ & $\begin{array}{l}30.77 \\
39 .\end{array}$ & $\begin{array}{l}33.08 \\
32 .\end{array}$ \\
\hline
\end{tabular}
リップを送ることである.ゆえにその場合のおのおのの （kg）重量を算出する．これはアウトレットテーブル上のパイ プの重量とインレットテーブル上のストリップの重量を 見出せばよい.

18. 結

3つの製品寸法による換算電流と主駆動モーターの電 流とを比較して Table 3 に列記した.

Table 3. Calculated resistance of each section \& main driving motor's load. 